\title{
The Effect of School Culture and Discipline on Teacher Performance at SMA Negeri Mesuji Makmur
}

\author{
Uspita $^{1 *}$, Bukman Lian ${ }^{1}$, Mulyadi $^{1}$
}

\author{
${ }^{1}$ Universitas PGRI Palembang \\ *Corresponding author. Email: us.pita81@gmail.com
}

\begin{abstract}
This study aimed to determine and describe school culture and discipline on teacher performance in SMA Negeri Mesuji Makmur. The population and sample in this study were 46 SMA teachers in Mesuji Makmur. The research method used was descriptive quantitative research using a questionnaire as an instrument. Data analysis in this research using simple and multiple linear regression through the SPSS version 25 for windows program. The research and data analysis results show that school culture has a strong influence on teacher performance. The magnitude of this influence is $62.30 \%$. Discipline has a strong effect on teacher performance. The magnitude of this influence is $47.80 \%$. School culture and discipline simultaneously have a significant impact on teachers' performance at SMA Negeri Mesuji Makmur. The magnitude of this influence is $62.70 \%$.
\end{abstract}

Keywords: School Culture, Work Discipline, Teacher Performance.

\section{INTRODUCTION}

Education aims to make education very important to ensure the development and continuity of a nation's life. Every Indonesian citizen has the right to receive education from elementary school to tertiary education. Increasing and equitable distribution of education is the top priority of the government. This is evident from the current National Education System regulated through the National Education System Law. In order to achieve the goals of National Education, professional teachers are needed so that education and learning will be of higher quality. Actually, leading to quality education and learning does not depend on just one component, namely the teacher, but as a system in one school [1]. These components include learning implementation programs, students, learning facilities and infrastructure, funds, community environment, and principal leadership. All components in the learning system are very important and determine the success of achieving educational goals. However, all of these components will not be useful for students in seeking the maximum learning experience, if they are not supported by the presence of professional teachers.

Many factors that can determine / influence the achievement of educational goals, including curriculum, infrastructure, quality of the learning process, financing management, human resource management (HR) and others. Among these factors, educators or teachers are the dominant factors in determining the achievement of educational goals. Educators are qualified academic personnel as tutors, lecturers, facilitators, and instructors suitable for their specialties and participate in organizing education [1].

The achievement of educational goals begins with the success of the learning process. The Teacher plays an important role, who directly interacts with students [2]. Therefore, the existence of professional and well-performing teachers is an absolute prerequisite for the creation of a quality education system and practice. Teachers are not just teaching, teachers are professional educators who must carry out their duties properly and with quality [2]. The success of education in the learning process is determined by teacher performance.

The teacher's performance is expected to function and behave in accordance with the assignment that has been assigned. The level of teacher performance is influenced by many things, including work effectiveness and efficiency, authority and responsibility, discipline, and initiative. Susanto [3] stated that a teacher's performance is influenced by several factors, including individual characteristics, external 
environment, and attitudes towards the employee profession. Based on this, the teacher's performance must be increased to create professional educators who are not only teachers but also educators. Improving the quality of teacher performance can be done through training activities, increasing selfdiscipline, good management of facilities and infrastructure, as well as support/motivation from the head as if he is the leader of the institution.

Fitria [4] states that the teacher is the main factor and affects the student learning process. In students' view, a teacher has authority, apart from authority in the academic field, the teacher also has authority in the non-academic field. Therefore, the teacher's influence on students is very large and very decisive. Teachers are a major factor in the world of education because without teachers, education goals will not be achieved. Eight standards must met in the implementation of education, including content standards, process standards, graduate competency standards, educators competency, and education personnel, facilities and infrastructure standards, management standards, financing standards, and education assessment standards (Government Regulation number 19 of 2005).

The teacher as the spearhead of the successful implementation of the learning process in schools has a big role and responsibility to manage all the class components. Teachers need to improve the quality of learning carried out to achieve the expected goals as they should. The role of a teacher is very important in carrying out learning and administering class and school administration. Without good performance from the teacher, the learning carried out will not produce anything useful and useful so that students will be left behind by the progress and demands of the ever-changing society. In other words, teacher performance means that there are competencies shown in the form of behavior that can complete work on time (efficiency), creative, innovative, and responsible for completing the work [5]. Teacher quality development and teacher performance appraisals are important things to do. The creation of good and productive teacher performance is influenced by many factors. Several factors that influence teacher performance are school culture and work discipline.

School culture as beliefs held by school personnel is the school element that guides school policies and consists of the right values [6]. Zuchdi [7] defines school culture as beliefs, policies, norms, and habits in schools that can be formed, strengthened, and maintained through school leaders and teachers. Meanwhile, according to Zamroni [8], school culture formed during the school's long course, including norms, values, habits, myths, and rituals.
Discipline is also another factor that can improve teacher performance. According to Fathoni [9], discipline is the most important operational function of Human Resource management because a good performance from a good discipline. Without good discipline, it is difficult for organizations to achieve optimal results. According to Simamora [10], discipline is a procedure that corrects or punishes subordinates for violating rules or procedures. In addition, Siagian [11] states that discipline is a management action to encourage organizational members to meet these various conditions' demands. Discipline in a company can be enforced if most of the rules are obeyed by most of its employees or employees. In practice, it is to ensure that every employee obeys all regulations.

School culture and discipline at SMA Negeri Mesuji Makmur are the main things that must be considered in creating a good performance. The results of observations while researchers show that there is a school culture that has not been cultured in some teachers and lack of discipline in some teachers. There are still some teachers who come late to school and there are some teachers who are not present to teach without giving assignments. In addition, there are still teachers who are present but leave teaching responsibilities in class and there are some teachers who do not make and own learning tools. Therefore, schools are required to immediately find a solution so that these problems can be resolved immediately. According to Edison [12] the variables that affect performance are Compensation, Systems or Procedures, Leadership, Company Culture and Environment, Communication, Competence, Motivation, and Discipline. Of the several variables contained in the model, researchers choose two variables to determine the effect of teacher performance, including school culture and discipline. From these problem, we are interested in examining how the influence of school culture and discipline on teacher performance in SMA Negeri Mesuji Makmur.

\section{METHODS}

The research method used in this research was descriptive quantitative research because it aims to describe or explain something as it is. This study wanted to know the impact of school culture factors or variables and discipline on teacher performance at SMA Negeri Mesuji Makmur with a sample of 46 respondents. The instrument of this research is questionnaire. Data analysis used simple and multiple linear regression through SPSS version 25 for windows.

\section{RESULTS AND DISCUSSION}

Based on the research results of hypothesis testing tested in this study, there are three hypotheses, including the partial hypothesis of the 
influence of school culture on teacher performance, the effect of discipline on teacher performance, and the influence of school culture and discipline on teacher performance.

Table 1. The results of the coefficient determination of the effect school culture on teacher performance analysis

\begin{tabular}{|c|c|c|c|c|c|c|c|c|}
\hline \multicolumn{9}{|c|}{ Model Summary } \\
\hline & & & & & Change $\mathrm{St}$ & tistics & & \\
\hline $\mathrm{R}$ & $\begin{array}{l}\text { R- } \\
\text { Square }\end{array}$ & $\begin{array}{l}\text { Adj. } \\
\text { Square }\end{array}$ & R- & Std. Error & $\begin{array}{l}\text { R-Square } \\
\text { Change }\end{array}$ & $\begin{array}{l}\text { F- } \\
\text { Change }\end{array}$ & df2 & Sig. F-Change \\
\hline $.790^{\mathrm{a}}$ & .623 & .615 & & 8.903 & .623 & 72.849 & 44 & .000 \\
\hline
\end{tabular}

Based on the first hypothesis test, the coefficient determination results using simple linear regression analysis of school culture's effect on teachers' performance based on the Model Summary's output value obtained the R number of 0.790 . So, We can say that school culture has a strong effect on teacher performance as evidenced by the correlation value between $0.600-0.799$. which is in the strong category [13] [14]. Standard Error of Estimated means measuring the variation from the predicted value. In this study, the standard deviation was 8,903 , the smaller the standard deviation, the better the model. Based on Table 1, the number obtained by the coefficient of determination R Square $=0.623$, which means that the percentage of school culture can significantly affect teacher performance in SMA Negeri Mesuji Makmur $62.30 \%$.

The simple linear regression analysis results (t-test), the effect of school culture on teacher performance at SMA Negeri Mesuji Makmur, analyzed using the SPSS software application aids version 25.0 is shown in Table 2.

Table 2. The results of hypothesis test the effect of school culture on teacher performance analysis

\begin{tabular}{|c|c|c|c|c|c|}
\hline Coefficients $^{\mathrm{a}}$ & $\begin{array}{l}\text { Unstan } \\
\text { Coeffic }\end{array}$ & $\begin{array}{l}\text { ardized } \\
\text { ents }\end{array}$ & $\begin{array}{l}\text { Standardized } \\
\text { Coefficients }\end{array}$ & & \\
\hline Model & B & $\begin{array}{l}\text { Std. } \\
\text { Error }\end{array}$ & Beta & $\mathrm{t}$ & Sig. \\
\hline $\begin{array}{ll}1 & \text { (Constant) } \\
& \text { school culture }\end{array}$ & $\begin{array}{l}28.384 \\
.785\end{array}$ & $\begin{array}{l}12.580 \\
.092\end{array}$ & .790 & $\begin{array}{l}2.256 \\
8.535\end{array}$ & $\begin{array}{l}.029 \\
.000\end{array}$ \\
\hline
\end{tabular}

The results of the simple linear regression analysis coefficient partially the influence of school culture on teacher performance, as shown in Table 2 , the constant coefficient (Constant) $=28.384$ and the school culture coefficient figure is 0.785 . So that the simple linear regression equation is obtained $\hat{Y}$ $=28.384+0.785 \mathrm{X}$, or the partial regression equation between the variables $\mathrm{X} 1$ to $\mathrm{Y}$ is $=28.384+$ $0.785 \mathrm{X} 1$. The results of the coefficient analysis obtained $\mathrm{t}_{\text {count }}$ of 8.535 and p-value of $0.000<0.005$, which means that $\mathrm{H} 0$ is rejected and $\mathrm{Ha}$ is accepted. Thus it can be said that partially stated that there is a positive influence of school culture on teacher performance at SMA Negeri Mesuji Makmur.

Table 3. The results of the coefficient determination of the effect discipline on teacher performance analysis

\begin{tabular}{|c|c|c|c|c|c|c|c|c|c|}
\hline \multicolumn{10}{|c|}{ Model Summary } \\
\hline \multirow{2}{*}{$\begin{array}{l}\text { Model } \\
1\end{array}$} & $\mathrm{R}$ & $\begin{array}{l}\mathrm{R} \\
\text { Square }\end{array}$ & $\begin{array}{l}\text { Adj. } \\
\text { Square }\end{array}$ & ${ }^{\mathrm{R}}$ Std. Error & $\begin{array}{l}\text { Change S } \\
\text { R-Square } \\
\text { Change }\end{array}$ & $\begin{array}{l}\text { tics } \\
\text { F-Change }\end{array}$ & df2 & $\begin{array}{l}\text { Sig. } \\
\text { Change }\end{array}$ & $\mathrm{F}$ \\
\hline & $.691^{\mathrm{a}}$ & .478 & .466 & 10.481 & .478 & 40.315 & 44 & .000 & \\
\hline
\end{tabular}

The result of the second hypothesis test, the results of the coefficient determination analysis using simple linear regression based on the Model Summary output value obtained the $\mathrm{R}$ number of 0.691. Thus, it can be said that discipline has a strong effect on the performance of teachers in SMA Negeri Mesuji Makmur, as evidenced by the correlation value between 0.600-0.800. Standard Error of Estimated (Standard Deviation) is 10.481. It can be seen in Table 3 that the figure obtained by the coefficient of determination R Square $=0.478$, which means that the percentage of the influence of work discipline is able to contribute to the 
performance of teachers in SMA Negeri Mesuji

Makmur by $47.8 \%$.

Table 4. The results of hypothesis test the effect of discipline on teacher performance analysis

\begin{tabular}{|c|c|c|c|c|c|}
\hline \multicolumn{6}{|l|}{ Coefficients $^{\mathbf{a}}$} \\
\hline \multirow[b]{2}{*}{ Model } & $\begin{array}{l}\text { Unstan } \\
\text { Coeffic }\end{array}$ & $\begin{array}{l}\text { ardized } \\
\text { ents }\end{array}$ & $\begin{array}{l}\text { Standardized } \\
\text { Coefficients }\end{array}$ & \multirow[b]{2}{*}{$\mathrm{t}$} & \multirow[b]{2}{*}{ Sig. } \\
\hline & B & $\begin{array}{l}\text { Std. } \\
\text { Error }\end{array}$ & Beta & & \\
\hline \multirow{2}{*}{$1 \quad \begin{array}{l}\text { (Constant) } \\
\text { Discipline }\end{array}$} & 50.135 & 13.482 & & 3.719 & .001 \\
\hline & .634 & .100 & .691 & 6.349 & .000 \\
\hline \multicolumn{6}{|c|}{ a. Dependent Variable: Teacher Performance } \\
\hline
\end{tabular}

Based on the second hypothesis test through partial linear regression analysis using ttest, the results of the coefficient of simple linear regression analysis partially the effect of discipline on teacher performance at SMA Negeri Mesuji Makmur as shown in Table 4. The constantcoefficient (Constant) is 50.135 and the coefficient number $\mathrm{X} 2=0.634$, so that the simple linear

Table 5. The results of the coefficient determination of the effect discipline and school culture on teacher performance analysis

\begin{tabular}{|c|c|c|c|c|c|c|c|c|c|}
\hline \multicolumn{10}{|c|}{ Model Summary } \\
\hline \multirow[b]{2}{*}{ Model } & \multirow[b]{2}{*}{$\mathrm{R}$} & \multirow[b]{2}{*}{$\begin{array}{l}\mathrm{R} \\
\text { Square }\end{array}$} & \multicolumn{7}{|c|}{ Change Statistics } \\
\hline & & & $\begin{array}{l}\text { Adjusted } \\
\text { R Square }\end{array}$ & $\begin{array}{l}\text { Std. Error of } \\
\text { the Estimate }\end{array}$ & $\begin{array}{l}\text { R Square } \\
\text { Change }\end{array}$ & $\begin{array}{l}\text { F } \\
\text { Chang } \\
\text { e }\end{array}$ & df1 & $\mathrm{df} 2$ & $\begin{array}{l}\text { Sig. F } \\
\text { Change }\end{array}$ \\
\hline 1 & $.792^{\mathrm{a}}$ & $\frac{1}{.627}$ & $\begin{array}{l}1.69 \\
.609\end{array}$ & 8.966 & .627 & 36.108 & 2 & 43 & .000 \\
\hline
\end{tabular}

The third hypothesis test through analysis of the coefficient of determination using multiple linear regression, multiple linear regression analysis results based on the Model Summary output obtained the $\mathrm{R}$ number is 0.792 . The multiple correlation value is between $0.600-0.800$ which is categorized as strong. This means that the influence of school culture and work discipline is able to make a strong contribution to the performance of teachers in SMA Negeri Mesuji Makmur with a standard regression equation is obtained $\hat{\mathrm{Y}}=50.135+0.634$ $\mathrm{X} 2$. The results of the coefficient analysis obtained $\mathrm{t}_{\text {count }}$ of 6.349 and $\mathrm{p}$-value $0.000<0.005$, which means that $\mathrm{H} 0$ is rejected and $\mathrm{Ha}$ is accepted. Thus it can be said that partially stated that there is a positive effect of discipline on teacher performance at SMA Negeri Mesuji Makmur.
Table 6. The results of hypothesis test the effect of discipline and school culture on teacher performance analysis

\begin{tabular}{|c|c|c|c|c|c|}
\hline \multicolumn{6}{|l|}{ Coefficients $^{a}$} \\
\hline \multirow{5}{*}{\begin{tabular}{ll}
\multicolumn{2}{l}{ Model } \\
1 & (Constant) \\
& school culture \\
& discipline
\end{tabular}} & $\begin{array}{l}\text { Unstand } \\
\text { Coeffici }\end{array}$ & $\begin{array}{l}\text { lardized } \\
\text { ents }\end{array}$ & $\begin{array}{l}\text { Standardized } \\
\text { Coefficients }\end{array}$ & \multirow[b]{2}{*}{$\mathrm{t}$} & \multirow[b]{2}{*}{ Sig. } \\
\hline & B & $\begin{array}{l}\text { Std. } \\
\text { Error }\end{array}$ & Beta & & \\
\hline & 28.433 & 12.669 & & 2.244 & .030 \\
\hline & .908 & .220 & .914 & 4.138 & .000 \\
\hline & -.126 & -.202 & -.137 & -.621 & .538 \\
\hline
\end{tabular}

Based on the third hypothesis test using the t-test, the results of the analysis of the multiple linear regression coefficients of the effect of school culture and discipline on teacher performance at deviation of 8.966, where the smaller the standard deviation means the better the model. Table 5 shows the coefficient of determination R Square (R2) is 0.627 . So that the influence of school culture and work discipline together can have a strong influence on teacher performance in SMA Negeri Mesuji Makmur of $62.7 \%$, while the remaining $38.3 \%$ was influenced by other factors not mentioned in this study.
SMA Negeri Mesuji Makmur, as shown in Table 6, obtained a constant coefficient $($ Constant $)=28.433$, simple regression coefficient. The influence of school culture on teacher performance in SMA 
Negeri Mesuji Makmur obtained a value of 0.908, a simple regression coefficient of the effect of work discipline on teacher performance at SMA Negeri Mesuji Makmur obtained a value of 0.126 . The multiple regression coefficient of school culture and discipline partially on teacher performance at SMA Negeri Mesuji Makmur, the score was 28.433. Based on the values obtained, the multiple linear regression coefficient $\mathrm{Y}=28.422+0.908 \mathrm{X} 1+-$ $0.126 \times 2$. From the results of the statistical value analysis for the variable coefficient of teacher performance $(\mathrm{Y}) \mathrm{t}$ count $=2.244$ and $\mathrm{p}$-value $=$ $0.030 / 2=0.015<0.05$ or $\mathrm{H} 0$ is rejected, which means that school culture and discipline have a positive effect on teacher performance in SMA Negeri Mesuji Makmur.

Table 7. The result of Multiple Linear Regression Analysis by Simultaneous (F-Test)

\begin{tabular}{|c|c|c|c|c|c|}
\hline \multicolumn{6}{|l|}{ ANOVA $^{a}$} \\
\hline Model & $\begin{array}{l}\text { Sum of } \\
\text { Squares }\end{array}$ & df & $\begin{array}{l}\text { Mean } \\
\text { Square }\end{array}$ & $\mathrm{F}$ & Sig. \\
\hline 1 Regression & 5805.699 & 2 & $\begin{array}{l}2902.84 \\
9\end{array}$ & 36.108 & $.000^{\mathrm{b}}$ \\
\hline Residual & 3456.910 & 43 & 80.393 & & \\
\hline Total & 9262.609 & 45 & & & \\
\hline
\end{tabular}

a. Dependent Variable: Teacher Performance

b. Predictors: (Constant), Discipline, School culture

Based on the third hypothesis test using the F-test formula as shown in Table 7 statistical value Fcount $=36.108$ and $p$-value $0.000<0.05$, meaning that $\mathrm{HO}$ is rejected, meaning that there is a linear influence on school culture and discipline variables on teacher performance. This also means that there is an influence of school culture and discipline together (simultaneously) on the performance of teachers at SMA Negeri Mesuji Makmur. In Indonesia, disciplinary character is highly emphasized in the 2013 curriculum in [15].

\section{CONCLUSION}

The conclusion of this study that there is an influence of school culture on teacher performance at SMA Negeri Mesuji Makmur. School culture has a strong influence on teacher performance, the magnitude of the influence of school culture on teacher performance is $62.30 \%$. There is an effect of work discipline on teacher performance at SMA Negeri Mesuji Makmurl. Discipline has a strong influence on the satisfaction of teachers and education staff, the magnitude of this influence is $47.8 \%$. There is a simultaneous influence of school culture and work discipline on teacher performance in SMA Negeri Mesuji Makmur. School culture and discipline simultaneously have a strong influence on teacher performance, the amount is $62.70 \%$. Some suggestions that can be contributed to this research include always paying attention to school culture and discipline that can provide a sense of comfort so that it can create a conducive atmosphere as well as direction, guidance, guidance for teachers as subordinates so that teachers work professionally and teacher performance can be. be better. For educators and education staff, they should always work professionally and with full responsibility, so that they can show better performance.

\section{REFERENCES}

[1] Mulyasa. (2011). Menjadi Guru Profesional Menciptakan Pembelajaran Kreatif dan Menyenangkan. Bandung: Remaja Rosdakarya.

[2] Little, O., Goe, L., \& Bell, C. (2009). A Practical Guide to Evaluating Teacher Effectiveness. National Comprehensive Center for Teacher Quality.

[3] Susanto, A. (2016). Manajemen Peningkatan Kinerja Guru. Jakarta: Prenada media Group

[4] Fitria., Mardalena., \& Arafat. (2020). Pengaruh Supervisi Akademik dan Kompetensi Profesional Guru terhadap Kinerja Guru di Sekolah Menengah Atas Negeri di Kecamatan Tanjung Raja. Diterbitkan dalam Jurnal Intelektualita: Keislaman, Sosial, dan Sains. Vol. 9, No. 1, http://jurnal.radenfatah.ac.id/index.php/inte lektualita.

[5] Fitriani., Herry., \& Lian. (2020). Pengaruh Kepemimpinan Kepala Sekolah dan Komitmen Guru terhadap Kinerja Profesional Guru. Diterbitkan dalam Jurnal Pendidikan Tambusai, 4(2) 2020.

[6] Daryanto. (2015). Pengelolaan Budaya dan Iklim Sekolah. Yogyakarta: Gava Media

[7] Zuchdi, D. (2011). Pendidikan Karakter dalam Perspektif Teori dan Praktik.Yogyakarta: UNY Press. 
[8] Zamroni. (2003). Paradigma pendidikan Masa Depan. Yogyakarta: BIDRAF Publishing

[9] Fathoni, A. (2006). Organisasi \& Manajemen Sumber Daya Manusia. Cetakan Pertama. Jakarta: PT Rineka Cipta

[10] Simamora, H. (2007). Manajemen Pemasaran Internasional Jilid II Edisi 2.Jakarta: PT Rineka Cipta

[11] Siagian, S. P. (2009). Manajemen Sumber Daya Manusia, Edisi.1, Cetakan.17 Jakarta, Bumi Aksara

[12] Edison, E. (2017). Manajemen Sumber Daya Manusia. Bandung: Alfabeta
[13] Arikunto, S. (2010). Prosedur Penelitian Suatu Pendekatan Praktek. Edisi Revisi. Jakarta: Rineka Cipta.

[14] Kesumawati, N. (2020). Pengaruh Manajemen Kepala Sekolah dan Profesionalisme Guru terhadap Kinerja Guru. online Jurnal Manajemen Pendidikan, Volume 2 Nomor 3, Juni 2020. Halaman 102-117.

[15] Pratiwi, U., \& Fasha, E. F. (2015). Pengembangan instrumen penilaian hots berbasis kurikulum 2013 terhadap sikap disiplin. Jurnal Penelitian dan Pembelajaran IPA, 1(1), 123-142. 